\title{
PENYULUHAN DAN FOGGING PENCEGAHAN DEMAM BERDARAH DENGUE (DBD) DI DESA PEKIK NYARING KECAMATAN PONDOK KELAPA BENGKULU TENGAH
}

\section{COUNSELING AND FOGGING IN PREVENTION TO DENGUE HEMORRHAGIC FEVER (DHF) IN PEKIK NYARING PONDOK KELAPA SUBDISTRICT IN CENTRAL BENGKULU}

\author{
Oleh: \\ Nugraheni Enny ${ }^{l}$, Lestari Novriantika ${ }^{1}$, Sundari Mulya ${ }^{2}$, Almira Sari ${ }^{1}$ \\ ${ }^{I}$ Fakultas Kedokteran dan Ilmu Kesehatan Universitas Bengkulu \\ ${ }^{2}$ RSUD M. Yunus Bengkulu \\ ennynugraheni@gmail.com,
}

\begin{abstract}
Dengue is a transmitted disease by mosquitoes that live in the tropical and subtropical. From the available data indicate that the South East Asia has the highest number of dengue both from mild to severe. Bengkulu Province is one of the five largest endemic areas of dengue fever in Indonesia. Therefore it takes more attention and seriously handling to reduce the incidence of dengue. In order to reduce outbreaks and the spread of dengue fever transmission, then the executive team felt the need to disseminate information to the public about how to break the chain of dengue fever transmission through hygienic behaviour and keep the environment clean. In these activities, the team is also taking action to kill the vector mosquitoes which is an intermediary vector of Aedes aegypti mosquitoes by fumigation or fogging. This activity consist of two phases, the first is the counseling activites and the second is fogging. For the counseling activities folowed by all cadres in Pekik Nyaring Village as much as 33 people. The counseling activities are very interactive because some participants expressed some questions and also in these activities there are several issues that raise in every village so that it can find the solution together. All cadres in Pekik Nyaring Village have to know and understand how to breaks the transmission of dengue and prevention methods to dengue fever attacks. After this activities, it's so expected to have more activity about preventing transmission of dengue regularly.
\end{abstract}

Keywords: Counseling, DHF, fogging

\section{PENDAHULUAN}

Dengue merupakan suatu penyakit yang ditransmisikan oleh nyamuk yang hidup didaerah tropis dan subtropis. Pada beberapa tahun terakhir penyebarannya meningkat pada daerah perkotaan yang telah menjadi perhatian masalah kesehatan di dunia internasional. (Idrees and Ashfaq, 2012) Dari data yang diperoleh Asia tenggara adalah yang memiliki jumlah tertinggi baik dari yang ringan sampai dengan yang berat (WHO, 2009).

Kejadian DBD di Indonesia tampak sesuai dengan siklus epidemik terjadi setiap 10 tahunan kemungkinan karena adanya perubahan iklim yang berpengaruh terhadap kehidupan vektor diluar faktor lain yang mempengaruhinya. Faktor perilaku dan partisipasi 
masyarakat yang masih kurang dalam kegiatan pemberantasan nyamuk serta faktor peningkatan mobilitas penduduk sehingga menyebabkan penyebaran virus DBD semakin mudah dan semakin luas (Kemenkes RI, 2010).

Pencegahan DBD dapat dilakukan dengan melakukan pencegahan salah satunya dengan memutuskan rantai transmisi penularan virus dengue. Perilaku hidup bersih dengan menjaga kebersihan lingkungan dengan mencegah berkembangbiaknya nyamuk Aedes Aegepty sebagai vektor perantara penyebaran virus dengue (WHO, 2012).

Masalah yang ditemukan pada masyarakat tentang penyakit DBD diantaranya: Prevalensi penyakit DBD (demam Berdarah Dengue) yang masih tinggi di Bengkulu khususnya di Desa Pekik Nyaring Bengkulu Tengah serta keasadaran masyarakat yang masih kurang tentang cara pencegahan penularan DBD di lingkungan rumah dan sekitar tempat tinggal. Sehingga tujuan dari kegiatan ini untuk memberikan pengetahuan tentang cara pencegahan penularan penyakit DBD dan melakukan pengasapan (fogging) untuk mencegah demam berdarah di Desa Pekik Nyaring Kecamatan Pondok Kelapa Bengkulu Tengah.

Berdasarkan masalah diatas maka diperlukan suatu kegiatan untuk meningkatkan kesadaran dan meningkatkan pengetahuan masyarakat tentang cara pencegahan penularan Demam Berdarah di Daerah tersebut. Kegiatan ini diharapkan menjadi pemicu ataupun penyegaran bagi masyarakat untuk meningkatkan kesadaran menjaga lingkungan sebagai salah satu faktor pengendalian pencegahan penyebaran Demam Berdarah Dengue. Selain kegiatan tersebut tim pelaksana merasa perlu melakukan kegiatan yang berdampak langsung bagi masyarakat yaitu dengan memutus rantai penularan Demam Berdarah Dengue dengan melakukan pengasapan atau fogging yang bertujuan membunuh nyamuk sebagai vektor perantara virus Dengue penyebab penyakit DBD. Hal ini diharapkan dapat menurunkan transmisi penularan penyakit DBD dan juga menurunkan angka kejadian DBD di Desa pekik Nyaring Kecamatan Pondok Kelapa Kabupaten Bengkulu Tengah.

\section{METODE PENGABDIAN}

Kegiatan pengabdian ini dilakukan dengan pendekatan metode penyuluhan, diskusi, dan pendekatan praktik. Adapun langkah-langkahnya adalah sebagai berikut:

1. Penyuluhan dan pelatihan diberikan kepada masyarakat tentang cara pencegahan Demam Berdarah Dengue (DBD)

2. Diskusi tentang cara pencegahan Demam Berdarah Dengue (DBD)

3. Pengasapan (fogging) di Lingkungan Dusun 3 Desa Pekik Nyaring.

\section{HASIL DAN PEMBAHASAN}

Kegiatan pengabdian masyarakat ini berlangsung selama dua tahap. Tahap pertama adalah melaksanakan kegiatan penyuluhan yang dihadiri oleh 33 peserta. Peserta tersebut adalah ibu ibu kader di Desa Pekik Nyaring. Pemilihan Ibu Kader sebagai peserta 
dikarenakan Ibu Kader sering berinteraksi dengan masyarakat disekitarnya dalam berbagai kegiatan sehingga diharapkan Kader di desa tersebut dapat menjadi perantara dalam menyampaikan informasi keseluruh masyarakat di Desa Pekik Nyaring. Kegiatan Penyuluhan dilaksanakan pada hari Jumat tanggal 20 November 2015 bertempat di Balai Dusun Blok III Desa Pekik Nyaring. Dari 33 orang kader yang diundang seluruh kader menghadiri kegiatan tersebut. Sebagai pembicara dalam kegiatan tersebut adalah anggota pengabdian dr. Novriantika Lestari. Acara tersebut di buka oleh Kepala Desa pekik Nyaring yaitu Bapak Sucipto, SE.

Dalam penyuluhan tersebut dibagi menjadi dua sesi. Sesi pertama pemaparan materi tentang DBD oleh tim kemudian sesi ke dua adalah tanya jawab. Pada sesi pertama yang berlangsung selama 1 Jam. Penyaji memaparkan tentang Demam Berdarah Dengue (DBD). Dalam pemeparan tersebut penyaji menyampaikan bagaimana penularan DBD, pencegahan serta mengetahui kegawatdaruratan dalam penyakit DBD. Penyajian dibantu dengan adanya alat bantu proyektor diserta dengan skema dan gambar sehingga mudah dimengerti oleh peserta penyuluhan.

Pada sesi kedua peserta dipersilahkan untuk memberikan pertanyaan kepada penyaji. Beberapa pertanyaan yang muncul diantaranya: Jika dalam suatu desa salah satu RT di fogging namun RT yang lain tidak apakah efektif? Apa saja tanda kegawatdaruratan DBD?, Kapan kita membawa anak ke dokter? Bagaimana cara memotivasi masyarakat untuk melakukan 3M? Apa perbedaan nyamuk penyebab DBD dan nyamuk Malaria? Beberapa pertanyaan yang disampaikan oleh peserta secara kesleuruhan dapat dijawab oleh penyaji sehingga peserta dapat memehami dan melakukan hal tersebut di rumah sendiri dan disebarluaskan ke masyarakat sekitar.

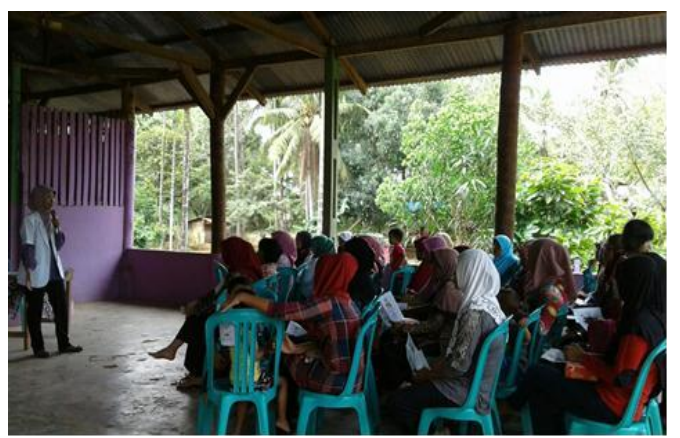

Gambar 1. Tim pengabdian memberikan penyuluhan kepada Kader Posyandu

Kegiatan tahap kedua fogging. Fogging dilakukan selama 2 hari di daerah yang belum melakukan fogging. Kegaiatan ini bekerjasama dengan Kades dan Puskesmas Pekik Nyaring. Dalam kegiatan fogging tersebut tim dari Puskesmas membantu dalam bentuk alat dan obat. 


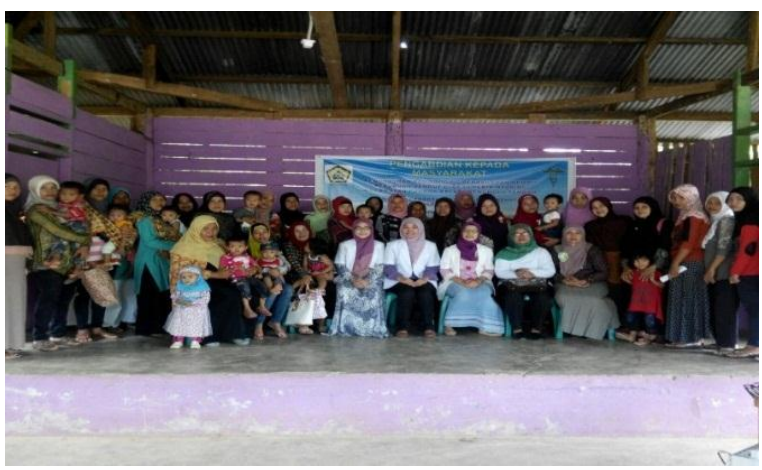

Gambar 2. Peserta kegiatan penyuluhan DBD

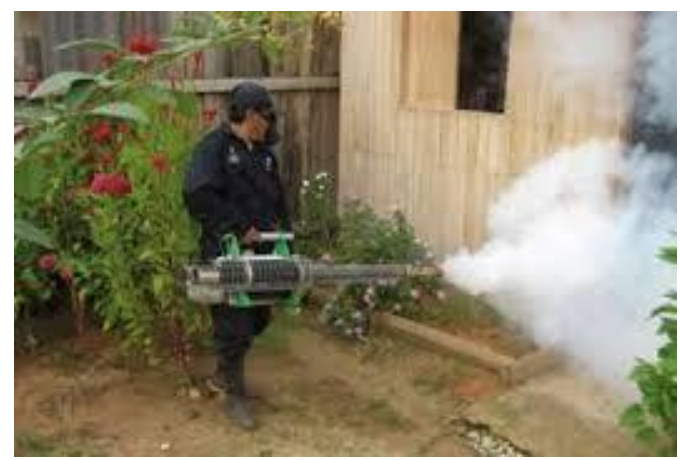

Gambar 3. Fogging yang dilakukan di sekitar wilayah pemukiman Desa Pekik Nyaring

\section{KESIMPULAN DAN SARAN}

Kesimpulan yang didapatkan dari kegiatan ini adalah Kader di Desa Pekik Nyaring telah memahami tentang pencegahan dan DBD dan juga memahami tentang penanganan kegawatdaruratan DBD. Saran kami terhadap mesayarakat tentang keberlanjutan kegiatan ini adalah diadakannya kegiatan gotong royong atau pencegahan demam berdarah secara berkala baik di Rumah ataupun dilingkungan sekitar rumah masyarakat desa Pekik Nyaring.

\section{DAFTAR PUSTAKA}

Idrees Sobia, Ashfaq Usman A., 2012, A Brief Review on Dengue Molecular Virology, Diagnosis, Treatment and Prevalence in Pakistan, Genetic Vaccine and Therapy, 10:6.

WHO, 2009, Dengue Guidelines for Diagnosis, Treatment, Prevention and Control.

Pusat Data dan Surveilans Epidemiolog Kementerian Kesehatan RI, 2010, Buletin Jendela Epidemiologi, Demam Berdarah Dengue.

WHO, 2012, Global Strategy Dengue Prevention and Control. 